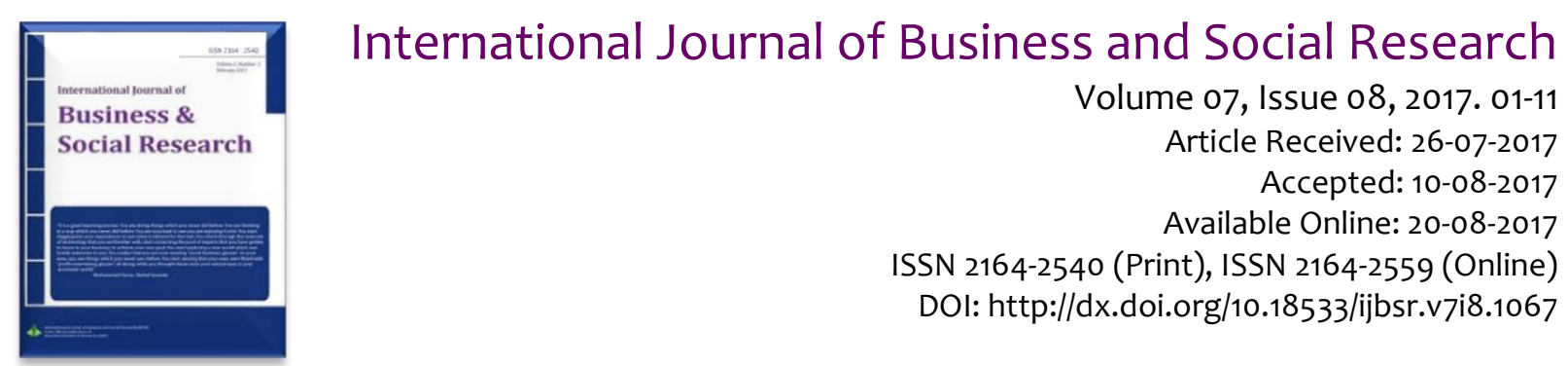

\title{
A Comparative Analysis between Commercial Banks and Insurance Companies in Bangladesh on the basis of Capital Structure
}

\author{
Shakila Zerin Bony', Md. Moniruzzaman²
}

\begin{abstract}
This research aims to compare the capital structure of Bangladeshi commercial banks and insurance companies. This research tries to identify how debt-equity mix influences firm performance in banks and insurance companies in Bangladesh. The annual financial statements of 10 commercial banks and 10 insurance Companies were used for this study which covers a period of five (5) years from 2011. 2015. The study assesses the capital structure of the commercial banks and insurance companies measured by total debt to equity ratio (DER), total debt to total funds ratio and performance by ROE, ROA, and EPS. Descriptive statistics, t-test have been used to show the differences between commercial banks and insurance companies capital structure and performance. However this study concludes that there is no significant difference between Bank and insurance companies EPS\& ROE but there is a significant difference between Bank and insurance company's D/A ratio, D/E ratio and ROA. We have tried to find out the significances of capital structure on depository and non-depository financial institutions from this study.
\end{abstract}

Keywords: Capital Structure, EPS, Return on Asset, Return on Equity, Total Debt to Total Equity Ratio (DER), and Total Debt to Total Funds Ratio.

JEL Codes: G2, G21, G22, G32.

This is an open access article under Creative Commons Attribution 4.0 License, 2017.

\section{Introduction}

Commercial Bank and Insurance Company both are financial institution have been two major sectors for the concern of investors. Bank is a financial intermediary that accepts deposits and channels those deposits into lending activities, either directly by loaning or indirectly through capital markets. A bank links together customers that have capital deficits and customers with capital surpluses. Insurance Company is a cooperative device to spread the loss caused by a particular risk over a number of persons, who are exposed to it and who agree to insure themselves against the risk. The principle of Insurance Company is to share the loss of each member of the society on the basis of probability of loss to their risk. There are 57 Commercial banks and 62Insurance Companies in Bangladesh. This study focuses on capital structure \& performance of listed Commercial banks and Insurance Companies in Bangladesh. The

\footnotetext{
${ }^{1}$ Assistant Professor, Department of Business Administration, Stamford University Bangladesh, Email:bonyshakila@gmail.com ${ }^{2}$ Senior Lecturer, Department of Business Administration, Stamford University Bangladesh, Email: mzaman.sub@gmail.com
} 
purpose of conducting this study is to measure the impact of capital structure on firms' performance to provide empirical evidence regarding Bangladeshi Banking Companies and Insurance Companies over a period of 2011 to 2015 and compare these two institutions regarding this issue. The significance of the study is to identify how debt-equity mix influences firm performance in banks and insurance companies in Bangladesh. Capital structure is one of the major topics among scholars in finance. Capital Structure in finance term means the way a firm finances his assets across the blend of debt, equity or hybrid securities (Saad, 2010). The concept is generally described as the combination of debt \& equity that make the total capital of firms. Capital structure decision is the vital one since the profitability of an enterprise is directly affected by such decision. The term "capital structure" of an enterprise is actually a combination of equity shares, preference shares and long term debts. Optimal capital structure represents the corporate financing mix. It can increase the value of the firm as well as the share price in the market.

Nonetheless, in the context of the banking industry, the subject has received a limited research attention. The study regarding the effects of capital structure on profitability will help us to know the potential problems in performance and capital structure. In order to conduct the research, a sample of 20 (twenty) listed companies from financial sector of Bangladesh have been used. The collected data have been analyzed through descriptive analysis, and t-test. We have tried to find out the significances of capital structure on depository and non-depository financial institutions from this study. The major findings of this study is to there is no significant difference between Bank and insurance company's EPS and ROE but there is a significant difference between Bank and insurance company's D/A ratio, D/E ratio and ROA. So it can be said that banking sector uses more debt than insurance company. This research paper has been conducted to achieve the followings objectives: to know about the capital structure and performance of Commercial Banks in Bangladesh, to know about the capital structure and performance of Insurance Companies in Bangladesh and to compare capital structure and performance between Commercial Bank and Insurance Company.

\section{Literature review}

Capital structure is one of the main constituents that could influence acutely to the firm's overall performance. Deteriorating returns occur with further use of debt in order to get the benefits of the tax deduction because of the existence of bankruptcy costs. This is why an appropriate capital structure beyond which maximizes in bankruptcy costs are higher than the marginal tax-sheltering benefits related to the additional substitution of debt for equity. By maintaining the appropriate capital structure or the optimal capital structure, firms are trying to minimize their financing cost along with maximizing the performance. According to Harris and Raviv (1991) capital structure is related to the trade-off between costs of liquidation and the gain from liquidation to both shareholders and managers. So more debt are available in the firm's capital structure than is suitable as it gains benefits for both shareholders and managers. underestimating the bankruptcy costs of liquidation or reorganization, or the aligned interest of both managers and shareholders, firms are maintaining more debt in their capital structure than they should which was stated in the previous literature (Harris and Raviv, 1991). Krishnanan and Moyer, (1997) argued that there is a negative and vital consequence of total debt to total equity (TD/TE) on return on equity (ROE). Gleason, Mathur and Mathur, (2000) discovered that firms performance is negatively influenced by firms capital structure which measures return on assets (ROA), growth in sales (Gsales), and pretax income (Ptax). Therefore, firm's performance declines for the high levels of debt in the capital structure.

There is a dilemma in the relationship between capital structure and firm's performance. Because some individuals got positive relationship; some got negative relationship while others got mixed or no relationship. Now we will discuss some of the major contributions to the literature on this topic in the below.

Roden and Lewellen (1995) found a positive relationship between profitability and capital structure employing a sample of 48 U.S. firms in an experiment during 1981-1990. Champion (1999), Ghosh, Nag, and Sirmans (2000), Hadlock and James (2002) observed analogous results. According to their findings, high-level of debts are observed in highly profitable firms.

Margaritis and Psillaki (2010) argued that there is a significant positive relationship between leverage and firm's performances. Their sample was consisting of both low and high growth French firms 
for the period 2003-2005 and they discovered a positive effect on firms' efficiency in respect to leverage over the entire sample.

According to the observation of Gleason, Lynette, and Ike (2000), that firm's capital structure has a statistically significant negative effect on firm's performance matrixes, i.e., return on assets (ROA), growth in sales (Gsales), and pretax income (Ptax). They found that if levels of debt in the capital structure is higher that would decrease the firm's performance.

Fama and French (2002) also observed a negative correlation between capital structure and firm's performance. They observed that high income generating firms with a minimum risk of financial distress are actually less levered and it directly contradicts with the trade-off theory.

The combination of a firm's long-term debt, specific short-term debt, common equity, preferred equity and retained earnings is called capital structure. All these are important elements to finance for a firm's overall operations and growth. Since the capital structure is directly related to the risk and return of a firm, it is a very significant financial decision. A high cost of capital may arise due to any immature capital structure decision; thus lowering firm's value while effective capital structure decision can do the opposite. Capital structure is defined in many ways by many scholars. Weston and Brigham (1979) defined capital structure as the permanent financing of the firm represented by long-term debt, preferred stock and net worth. Van Horne and Wachowicz (1995) suggested capital structure is the mix of a firm's permanent long-term financing represented by debt, preferred stock, and common stock equity. Therefore it is explicit that capital structure combines mainly equity and long-term debt. Short-term debt is not traditionally considered in the capital structure. Both the researchers and academicians are studying capital structure theoretically and empirically for many years, but it came into forward to the financial economists after Modigliani and Miller's (1958) "irrelevance theory of capital structure" (hereafter referred to as $M M$ theory). All researchers agree that there is an optimal capital structure for the firm; which maximizes the value of the firm and simultaneously minimizes the cost of capital thus tradeoff between risk and return. Firms should provide a precise methodology to the financial managers for determining a firm's optimal capital structure. However, it is not possible yet (Gitman\&Zutter, 2010). Many studies were emphasized in finding the optimal capital structure. After MM propositions. Even though $M M$ theory is established on some unrealistic assumptions, for example, the assumption of perfect capital markets which provides us a basis to perform research on capital structure. Four major theories of capital structure was developed earlier; such as the trade-off theory, agency costs theory, pecking order theory, and market timing theory. Modigliani and Miller (1958) suggested under perfect capital markets assumption, firm's value is not influenced by the capital structure. Many researchers criticized the theory objecting that in reality there are no perfect capital markets, they revised their previous theory through incorporating tax benefit later and found that interest payments are tax deductible under market imperfection, the value of the firm will rise with the level of financial leverage (Modigliani \& Miller, 1963).

Capital structure decisions may have important significances for the value of the firm and its cost of capital (Firer et al, 2008). Unjustified and weak capital structure decisions can lead to an increased cost of capital thereby dropping the net present value (NPV) of the firms. However, many investment projects is unacceptable by the firms. (Known as the underinvestment problem). The decision of effective capital structure will decrease the firm's overall cost of capital and increase the NPV of investment projects leading to more projects being acceptable to undertake. And consequently, it will increase the overall value of the firm (Gitman, 2003). Despite the significance that capital structure can play in enhancing the value to the firm decades worth of theoretical literature and empirical testing have not been able to give guidance to researchers with regards to the choice between debt and equity in their capital structures (Frank and Goyal, 2009).

The role of business risk, taxes, managerial behavior or financial flexibility in the analysis of firm performance is recommended by Akintoye (2009). He suggested that capital structure is formed on the basis of the positive relationship between risk and return which are the vital factors to determine a target capital mix. The companies are guided by the ideal mix of debt and equity which minimizes the cost of capital and maximizes the company value. It was discovered by the Chinese firms that there is a negative relationship between Leverage and performance which was analyzed by the ratio of EBIT to total assets. (Huang and Song, 2006; Chakraborty, 2010). Profitable companies mainly focus on liquidity compare to leverage in order to minimize risks. (Serghiescu and Vaidean, 2013). 
We can conclude from the above discussion that the all the theories of capital structure helps to identify whether the capital structure has any impact on firm's performance or not. In many extensive empirical types of research, the relationship between capital structure and firm's performance have been studied. Although Bangladesh cannot go far to this literature. We try to bring the changes of this scenario. Nonetheless, this research aims to investigate the relationship between capital structure choices and firm's performance.

\section{Research methodology}

In order to conduct the research, a sample of 20 (twenty) listed companies from financial sector of Bangladesh have been used. Annual reports of the sampled companies for the year 2011 to 2015 were collected. Again, website of commercial banks and insurance companies, different periodicals published by the two sectors and research articles has been used. The collected data have been analyzed through descriptive analysis, and t-test. Performance has been measured through Return on Equity (ROE), Return on asset (ROA), and EPS where capital structure has been measured through Total Debt to Total Equity Ratio (DER), and Total Debt to Total Funds Ratio.

The following hypotheses have been conducted to complete this paper.

1. Ha: There is significant difference between commercial banks and insurance companies $D / A$ ratio.

2. Ha: There is significant difference between commercial banks and insurance companies $D / E$ ratio.

3. Ha: There is significant difference between commercial banks and insurance companies EPS.

4. Ha: There is significant difference between commercial banks and insurance companies ROA.

5. Ha: There is significant difference between commercial banks and insurance companies ROE.

\section{Industry background}

\subsection{Banking Industry}

The financial sector's contribution in Bangladesh to GDP has remained static at 1.5 percent during 1999-2000 periods. Commercial banks are at the heart of this financial sector by contributing $80 \%$ of the total. Relative stability achieved by the support extended by both the central bank and the Government of Bangladesh in the past has restored public confidence in the country's banking sector.

Moreover, Nationalized Commercial Banks (NCBs) and old generation Private Commercial Banks (PCBs) would have to lower the rate of NPAs in their portfolios. Failure to do so would mean recapitalization, at least for the NCBs. This may in turn lead to a further drain on the limited resources of the Government of Bangladesh. At this time or in the immediate future this re-capitalization would not be feasible. With these conditions in place, the World Bank anticipates the likelihood of a situation where the ever-increasing burden of non-performing loans and growing rate of debt servicing would place the economy under enormous strain and result in a crisis in the banking sector in the long term.

\subsection{Insurance company}

Insurance Business in Bangladesh is one of the common phenomenon traditional businesses. This business has a long history. Insurance business in Bangladesh started almost century back for the during the British regime in India, some insurance companies began business operation, both life and general. Bangladesh Insurance business increased for the duration of 1947-1971, when there are 49 insurance companies operate their business both life and general insurance. In that time Twenty seven Insurance company head office in Bangladesh former West Pakistan and Ten Insurance company head office in East Pakistan.

After liberation war in 1972 The People's Republic Government of Bangladesh nationalized the insurance industry along with the banks in 1972 by Presidential Order No. 95. By virtue of this order, all insurance company in Bangladesh operate they are businesses under this nationalization order.

\subsubsection{Selected commercial banks and insurance companies}

10 Commercial Banks and 10 Insurance Companies have been selected for the study. 
Table 1: Selected institutions

\begin{tabular}{|c|c|}
\hline Commercial Bank & Details \\
\hline AB Bank & $\begin{array}{l}\text { Incorporated in Bangladesh on } 31 \text { st December } 1981 \text { as Arab } \\
\text { Bangladesh Bank Limited and started its operation with effect from } \\
\text { April12,1982 }\end{array}$ \\
\hline Southeast Bank & $\begin{array}{l}\text { Established in } 1995 \text { with a dream and a vision to become a pioneer } \\
\text { banking institution of the country }\end{array}$ \\
\hline Bank Asia & $\begin{array}{l}\text { Incorporation on September } 28,1999 \text { and came to operation on } \\
\text { November } 27,1999 .\end{array}$ \\
\hline BRAC Bank & $\begin{array}{l}\text { Founded on } 4 \text { July } 2001 \text { as a private commercial bank focused on } \\
\text { Small and Medium Enterprises (SME). }\end{array}$ \\
\hline City Bank & $\begin{array}{l}\text { Started its journey on } 27 \text { th March } 1983 \text {. It is a top bank among the } \\
\text { oldest five Commercial Banks in the country }\end{array}$ \\
\hline Dhaka Bank & $\begin{array}{l}\text { Started its commercial operation on July 05, } 1995 \text { with an authorized } \\
\text { capital of Tk. 1,000 million and paid up capital of Tk. } 100 \text { million. }\end{array}$ \\
\hline Dutch-Bangla Bank & Has launched the first mobile ATM booth in Bangladesh. \\
\hline Eastern Bank & $\begin{array}{l}\text { Began its journey in } 1992 . \text { Over the years EBL has established itself as } \\
\text { a leading private commercial bank in the country. }\end{array}$ \\
\hline IFIC Bank & $\begin{array}{l}\text { Listed with Dhaka Stock Exchange Ltd. and Chittagong Stock } \\
\text { Exchange Ltd. Authorized Capital of the Bank is Tk. 20,000.00 Million } \\
\text { (\$257.23 Million) and Paid-up Capital is Tk. 14,636.28 Million ( } \$ 188.25 \\
\text { Million) having shareholders as on 30th June } 2013 \text {. }\end{array}$ \\
\hline Jamuna Bank & $\begin{array}{l}\text { Started its operation from } 3 \text { rd June 2001. Provides all types of } \\
\text { support to trade, commerce, industry and overall business of the } \\
\text { country. }\end{array}$ \\
\hline
\end{tabular}

Karnaphuli

Company Limited

Insurance

Pioneer Insurance Company

Limited

Eastland Insurance Company Limited

Green Delta Insurance Company Limited

Popular Life Insurance Company Limited Shandhani Life Company Limited

Insurance

MetLife life Insurance Company Limited

National life Insurance Company Limited
Details

Bangladesh Bank Limited and started its operation with effect from April12,1982

banking institution of the country

Incorporation on September 28, 1999 and came to operation on

Founded on 4 July 2001 as a private commercial bank focused on Small and Medium Enterprises (SME).

oldest five Commercial Banks in the country

Started its commercial operation on July 05, 1995 with an authorized

Has launched the first mobile ATM booth in Bangladesh.

Began its journey in 1992. Over the years EBL has established itself as

Listed with Dhaka Stock Exchange Ltd. and Chittagong Stock Exchange Ltd. Authorized Capital of the Bank is Tk. 20,000.00 Million (\$257.23 Million) and Paid-up Capital is Tk. 14,636.28 Million (\$188.25 Million) having shareholders as on 30th June 2013

support to trade, commerce, industry and overall business of the

Started its operation from 3rd June 2001. Provides all types of support to trade, commerce, industry and overall business of the country.

Pioneer Insurance Company Limited sponsored \& founded in 1996 is a publically traded company. The company is established with DSE \& CSE and has been declaring dividend every year since inception.

Eastland Insurance Company Limited is a first generation insurance company was incorporated on November 5 1986as a public Itd. Company under the companies Act 1913 with the vision to be one of the premier non-life insurance company in Bangladesh.

Green Delta Insurance Company Limited is one of the leading non-life insurance company in Bangladesh. GDIC was incorporated in December 14, 1985 as a public Itd. Company under companies Act 1913 \& its operation started on $1^{\text {st }}$ January 1986.

This insurance company establishes by group of local enthusiastic entrepreneur started its operation in Sept. 26, 2000.

Shandhani Life Insurance Company Limited is one of the leading life insurance company in Bangladesh since 1990.SLIC enlarge its network by establishing its agency offices. As a result in $31^{\text {st }}$ December 20149.09 lac policy holder is now under the shade of Shandhani.

MetLife is among the largest global provider of insurance, annuity \& employee benefit program with 90 million customers in over 60 countries.

National life Insurance Company Limited is the first private sector life insurance company in Bangladesh, incorporated on 12 February 1985 as a public Itd. Company under companies Act 1913 to engage in life 
insurance business according to the provision of Insurance Act 1938 \& rules 1958.

City General Insurance City General Insurance Company Limited is the second generation Company Limited non-life insurance company incorporated as public Itd. Company on March 18, 1996 under companies Act 1994.

Northern General Insurance Northern General Insurance Company Ltd. Is one of the leading Company Limited general insurance company in Bangladesh was corporate on April 8,1996 as public Itd. Company under companies Act 1938 in order to run all types of general insurance business other than life insurance business.

Source: Websites listed banks and insurance companies

\section{Result and discussion}

\subsection{Total debt to total funds}

This variable refers to the Total Debt to Total Fund over the years and its influence on the banks and insurance company's performance. Normally it is believed that, there is a negative D/A ratio and firm's performance.

Table 2: Bank and insurance company's Total D/A ratio scenario

\begin{tabular}{lrrrr}
\hline Year & Bank & $\begin{array}{r}\text { Total D/A ratio } \\
\text { Insurance Company }\end{array}$ & Bank & $\begin{array}{r}\text { Increase/Decrease } \\
\text { Insurance Company }\end{array}$ \\
\hline 2011 & 9.02 & 7.1091 & & $-2.68 \%$ \\
2012 & 9.11 & 6.9235 & $0.99 \%$ & $6.74 \%$ \\
2013 & 9.13 & 7.4239 & $0.22 \%$ & $4.35 \%$ \\
2014 & 8.95 & 7.7662 & $-2.01 \%$ & $0.59 \%$ \\
2015 & 9.20 & 7.8124 & $2.72 \%$ & \\
\hline
\end{tabular}

Source: Annual reports of commercial bank and insurance company

In case of selected 20 banks and insurance companies, it has been found that D/A ratio were fluctuating over time. From 2011 to 2013 bank was increased more than insurance co. because in 2012 insurance company's D/A ratio was highly decrease but then up to 2015 it was positively increase. On the other side in 2014 bank's D/A ratio was decreased and then increase in 2015.

\subsection{Total debt to total equity}

This variable refers to the Total Debt to equity over the years and its influence on the banks and insurance company's performance. Normally it is believed that, there is a negative D/E ratio and firm's performance

Table 3: Bank and insurance company's Total D/E ratio scenario

\begin{tabular}{lrrrr}
\hline & \multicolumn{3}{c}{ Total D/E ratio } & Increase/Decrease \\
\hline Year & Bank & Insurance Company & Bank & Insurance Company \\
\hline 2011 & 97.047 & 47.446 & & \\
2012 & 110.003 & 42.275 & $11.78 \%$ & $-12.28 \%$ \\
2013 & 109.363 & 51.089 & $-0.59 \%$ & $17.25 \%$ \\
2014 & 119.124 & 58.917 & $8.19 \%$ & $13.29 \%$ \\
2015 & 121.312 & 59.001 & $1.80 \%$ & $0.14 \%$ \\
\hline
\end{tabular}

Source: Annual reports of commercial bank and insurance company

From table, it is seen that, in 2012 banks D/E ratio was increase and decrease in 2013 and finally up to 2015 it was positively increase. But in insurance company in 2012 it was negative and then up to 2015 increase positively. 


\subsection{Return on asset}

This variable refers to the ROA over the years. Higher the value, better it is.

Table 4: Total ROA ratio scenarios for banks and insurance companies

\begin{tabular}{lrrrr}
\hline & \multicolumn{2}{c}{ ROA } & Increase/Decrease \\
\hline Year & Bank & Insurance Co. & Bank & Insurance Co. \\
\hline 2011 & $29.95 \%$ & $19.11 \%$ & & \\
2012 & $40.06 \%$ & $19.67 \%$ & $0.3376 \%$ & $0.0293 \%$ \\
2013 & $31.02 \%$ & $15.97 \%$ & $-0.2257 \%$ & $-0.1881 \%$ \\
2014 & $16.85 \%$ & $11.80 \%$ & $-0.4568 \%$ & $-0.2611 \%$ \\
2015 & $21.09 \%$ & $10.74 \%$ & $0.25163 \%$ & $-0.0898 \%$ \\
\hline
\end{tabular}

Source: Annual reports of commercial bank and insurance company

From table, it is seen that, in 2013 and 2014, both institution's ROA ratio were negative. In 2015, insurance companies' ratio was negative where banks ratio was positive.

5.4 Return on equity

This variable refers to the ROE over the years. Higher the value, better it is.

Table 5: Total ROE ratio scenario for banks and insurance companies

\begin{tabular}{lrrrr}
\hline & \multicolumn{3}{c}{ ROE } & Increase/Decrease \\
\hline Year & Bank & Insurance Co. & Bank & Insurance Co. \\
\hline 2011 & $205.58 \%$ & $259.22 \%$ & & \\
2012 & $235.98 \%$ & $255.08 \%$ & $0.14787 \%$ & $-0.01597 \%$ \\
2013 & $210.33 \%$ & $181.17 \%$ & $-0.1087 \%$ & $-0.28975 \%$ \\
2014 & $134.94 \%$ & $127.64 \%$ & $-0.3584 \%$ & $-0.29547 \%$ \\
\hline
\end{tabular}

Source: Annual reports of commercial bank and insurance company

From table, it is seen that, all the years insurance companies ROE were negative where banks ROA were fluctuating.

\section{$5.5 \quad$ EPS}

In an efficient market, the theory of market efficiency says that the market takes some hikes from the EPS data. This report considers earnings per share (EPS) as the measure of profitability. Prior literatures do not use this kind of variable. This study considers EPS which will be the most perfect measure of profitability which is affected by capital structure.

Table 6: Total EPS ratio scenario for banks and insurance companies

\begin{tabular}{lrrrr}
\hline & & EPS & \multicolumn{2}{c}{ Increase/Decrease } \\
\hline Year & Bank & Insurance Co. & Bank & Insurance Co. \\
\hline 2011 & 43.42 & 42.42 & & \\
2012 & 30.57 & 31.24 & $-42.04 \%$ & $-35.79 \%$ \\
2013 & 36.14 & 30.68 & $15.41 \%$ & $-1.83 \%$ \\
2014 & 44.50 & 47.19 & $18.79 \%$ & $34.99 \%$ \\
2015 & 54.01 & 56.91 & $17.61 \%$ & $17.08 \%$ \\
\hline
\end{tabular}

Source: Annual reports of commercial bank and insurance company

From table, it is seen that, in 2012 both institution's EPS were negative. But from 2014 to 2015 both institution were positive though in 2013 insurance company's was negative.

\subsection{Descriptive Statistics}




\subsubsection{For banks}

Table provides a summary of the descriptive statistics for the dependent and independent variables for the sample banks. It shows that over the period under study, the profitability ratios measured by EPS, return on asset, and return on equity averaged $4.1728,0.2779$ and 0.1899 respectively. The debt/equity ratio stood at 11.1370 and debt to total funds averaged 0.9082 . This indication that approximately $91 \%$ of total assets in the banking sector of Bangladesh are represented by debt, confirming the fact that banks are highly geared institutions. The maximum and minimum values for debt/equity ratio indicate that the debt/equity composition varies substantially among the listed banks in Bangladesh.

Table 7: Summary of descriptive statistics

\begin{tabular}{lrrrrr}
\hline Variable & Obs & Mean & Std. Dev. & Min & Max \\
\hline Eps 1 & 50 & 4.1728 & 2.378886 & 1.2 & 11.6 \\
Roa 1 & 50 & 0.2779 & 0.0193349 & 0.0035 & 0.0352 \\
Roe 1 & 50 & 0.1899 & 0.0883804 & 0.043 & 0.03984 \\
Dta 1 & 50 & 11.1370 & 0.0269904 & 0.83081 & 0.09467 \\
Dte 1 & 50 & 0.9082 & 2.945771 & 5.48197 & 17.7942 \\
\hline
\end{tabular}

\subsubsection{For insurance company's}

Table provides a summary of the descriptive statistics for the dependent and independent variables for the sample non-banks. It shows that over the period under study, the profitability ratios measured by EPS, return on asset, and return on equity averaged 4.168, 0.0154 and 0.177 respectively. The debt/equity ratio stood at 5.1749 and debt to total funds averaged 0.7407 .This indication that approximately $73 \%$ of total assets of insurance company in Bangladesh are represented by debt, confirming the fact that insurance companies are less highly geared institutions compared to bank. The maximum and minimum values for debt/equity ratio indicate that the debt/equity composition varies substantially among the listed insurance company's in Bangladesh.

Table 8: Summary of descriptive statistics

\begin{tabular}{lrrrrr}
\hline Variable & Obs & Mean & Std. Dev. & Min & Max \\
\hline Eps 1 & 50 & 4.168 & 2.774043 & 0.02 & 10.65 \\
Roa 1 & 50 & 0.0154 & 0.9786853 & -0.00115 & 2.18 \\
Roe 1 & 50 & 0.177 & 0.807594 & 0.0282 & 26.2 \\
Dta 1 & 50 & 0.7407 & 0.1927561 & 0.213077 & 0.940832 \\
Dte 1 & 50 & 5.1749 & 4.285209 & 0.034241 & 15.90088 \\
\hline
\end{tabular}

\subsubsection{Comparative analysis between bank and insurance company's performance through descriptive statistics}

Table 9: Comparative analysis through descriptive statistics

\begin{tabular}{lrrrrr}
\hline Mean & EPS & ROA & ROE & D/A ratio & D/E ratio \\
\hline Bank & 4.1728 & 0.2779 & 0.1899 & 0.9082 & 11.1370 \\
Insurance Co. & 4.168 & 0.0154 & 0.177 & 0.7407 & 5.1749 \\
\hline
\end{tabular}

The above table shows the banks and insurance company's EPS, ROA, ROE, D/A and D/E ratio. It is seen that Banking and Insurance Company's EPS\& ROE does not vary significantly, but ROA, D/E and D/A ratio vary significantly. Banks ROA and ROE are good than insurance company and also less levered firm than banks. We can see that Banks use almost $91 \%$ debt to form their asset and where insurance company use $73 \%$ debt. Similarly their $\mathrm{D} / \mathrm{E}$ ratio is higher than insurance company.

\subsection{Comparative analysis of bank and insurance company through t- statistics}

\subsubsection{D/A ratio}




\begin{tabular}{lrrr}
\hline Mean Score & Bank' Mean Score & $\begin{array}{r}\text { Insurance Company's Mean } \\
\text { Score }\end{array}$ & t-Test Score Ho: $\mu=3$, Ha: $\mu \neq 3$ \\
\hline 0.8245 & 0.9082 & 0.7407 & $2.72^{* *}$ \\
\hline${ }^{*}<0.05 ;{ }^{* * P}>0.05$ & &
\end{tabular}

From the Mean score of 0.8245 , it can be inferred that majority accept that there is a significant difference between bank and insurance company's capital structure. So Ha is accepted. Here from the banks and insurance company's individual mean score, it is observed a difference between their D/A ratio. Banks are a way more D/A ratio than insurance company in this regard. The t-test score also disclose the $\operatorname{fact}(t=2.72, p>0.05)$.

\subsubsection{D/E ratio}

\begin{tabular}{lrrr}
\hline Mean Score & Bank' Mean Score & $\begin{array}{r}\text { Insurance Company's Mean } \\
\text { Score }\end{array}$ & t-TestScoreHo: $\mu=3$, Ha: $\mu \neq 3$ \\
\hline 8.1560 & 11.1370 & 5.1749 & $3.665^{* *}$ \\
\hline${ }^{* P}<0.05 ;{ }^{* * P}>0.05$ & &
\end{tabular}

From the Mean score of 8.1560 , it can be inferred that majority accept that there is a significant difference between bank and insurance company's capital structure. So Ha is accepted. Here from the banks and insurance company's individual mean score, it is observed a difference between their D/E ratio. Banks are a way more $\mathrm{D} / \mathrm{E}$ ratio than insurance company in this regard. The t-test score also disclose the fact $(t=3.665, p>0.05)$.

\subsubsection{EPS}

\begin{tabular}{lrrr}
\hline Mean Score & Bank' Mean Score & $\begin{array}{r}\text { Insurance Company's Mean } \\
\text { Score }\end{array}$ & t-TestScoreHo: $\mu=3$, Ha: $\mu \neq 3$ \\
\hline 4.1704 & 4.1728 & 4.168 & $0.0042^{*}$ \\
\hline
\end{tabular}

${ }^{*} P<0.05 ; * * P>0.05$

From the Mean score of 4.1704 , it can be inferred that majority accept that there is not a significant difference between bank and insurance company's EPS. So Ho is accepted. Here from the banks and insurance company's individual mean score, it is observed a very slight difference between their EPS. The t-test score also disclose the fact $(t=0.0042, p<0.05)$.

\subsubsection{ROA}

\begin{tabular}{lrrr}
\hline Mean Score & Bank' Mean Score & $\begin{array}{r}\text { Insurance Company's Mean } \\
\text { Score }\end{array}$ & t-TestScoreHo: $\mu=3$, Ha: $\mu \neq 3$ \\
\hline 0.14665 & 0.2779 & 0.0154 & $1.3416^{* *}$ \\
\hline$* P<0.05 ; * * P>0.05$ & & &
\end{tabular}

From the Mean score of 0.14665 , it can be inferred that there is a significant difference between banks and insurance company's ROA. So Ha is accepted. Here from the banks and insurance company's individual mean score, it is observed difference between their ROA. The t-test score also disclose the fact $(t=1.3416, p>0.05)$.

\subsubsection{ROE}

\begin{tabular}{lrrr}
\hline Mean Score & Bank' Mean Score & $\begin{array}{r}\text { Insurance Company's Mean } \\
\text { Score }\end{array}$ & t-TestScoreHo: $\mu=3$, Ha: $\mu \neq 3$ \\
\hline 0.1935 & 0.1899 & 0.177 & $0.0175^{*}$ \\
\hline${ }^{*}<0.05 ; * * P>0.05$ & & &
\end{tabular}


From the Mean score of $\mathbf{0 . 1 9 3 5}$, it can be inferred that there is not a significant difference between banks and insurance company's ROE. So Ho is accepted. Here from the banks and insurance company's mean score, it is observed very slight difference between their ROE. The t-test score also disclose the fact $(t=0.0175, p<.05)$.

The following discussions are suggested for banking and insurance company of Bangladesh to improve their performance.

1) Banking sector should reduce dependency on debt capital and increase equity capital.

2) Insurance company should increase their EPS.

3) Banking sector should increase their ROA.

4) Banking sector and insurance company both should increase their ROE.

\section{Conclusion}

Bank and insurance company play a crucial role in our economy. A bank links together customers that have capital deficits and customers with capital surpluses. Insurance company is a non-depository financial institution that provides protection from financial loss. It is a form of risk management primarily used to hedge against the risk of a contingent, uncertain loss. There are 57 banks and 62 Insurance Company in Bangladesh. The current research is restricted only to the listed banks \& Insurance companies (10 banks and 10 insurance companies) in Bangladesh. The sample size is small in this context. This study focuses on capital structure of both banking and insurance Company. Generally firm's capital structure has a significant and negative impact on the firm's performance. In this study, it is tried to find out that whether there is any differences between banks and insurance company's capital structure and performance or not. For this, descriptive statistics, t-test have been used. It is found that that there is no significant difference between Bank and insurance company's EPS and ROE but there is a significant difference between Bank and insurance company's D/A ratio, D/E ratio and ROA. So it can be concluded that banking sector uses more debt than insurance company. This paper will give insight about capital structure of banking and insurance company and help the management of those sectors to make optimal capital structure to create value of their firm.

\section{Limitations and scope of future research}

There are 57 commercial banks and 62 Insurance Companies are available in Bangladesh. The current research is restricted only to the listed banks \& Insurance companies (10 banks and 10 insurance companies) in Bangladesh. The sample size is small in this context. The research is done mainly through secondary data collection. There are some others data collection methods which are not followed. So it can be said that it may not be $100 \%$ accurate. Here we use the data from the period of 2011-2015. The true picture of comparison is not illustrated considering the five years.

The research has compiled a large database of listed bank's and insurance company's accounting data that demonstrate what can be done even with the limitations of currently available data. There is clearly enormous scope for more research that can inform an understanding of how the capital is structured, how it connects with the profitability and other areas are available for making the comparison. To develop specific policy recommendations we suggest the following for further research;

1. There are 57 commercial banks and 62 Insurance Companies are available in Bangladesh. Only 10 banks and 10 insurance companies are used to conduct the research. Other banks and insurance companies are available for making the comparison.

2. Here we have made a comparison between banks and insurance companies. There are some other areas to make the comparison like finance companies, leasing companies and mutual funds.

3. There are some other variables are available for making the comparison as well.

\section{References}

Akintoye, I.R. (2009) Sensitivity of Performance to Capital Structure, Banking and Finance Letters, 1(1), pp.29-35

Chakraborty, I. (2010) Capital structure in an emerging stock market: The case of India, Research in International Business and Finance,24(3), pp.295-314 
Champion, D. (1999). Finance: The joy of leverage. Harvard Business Review, 77(4), 19-22.

Fama, E. F., \& French, K. R. (2002). Testing trade-off and pecking order prediction, about dividends and debt. Review of Financial Studies, 15(1), 1-33.

Ghosh, C., Nag, R., \&Sirmans, C. (2000). The pricing of seasoned equity offerings: evidence from REITs. Real Estate Economics, 28(3), 363-84.

Gitman, L. J. (2003). Principles of Managerial Finance, International Editions Financial Series.

Gleason, K. C., Lynette, K M., \& Ike, M. (2000). The Interrelationship between culture, capital structure, and performance: Evidence from European retailers. Journal of Business Research, 50(2), 185-191.

Hadlock, C., \& James, C. (2002). Do banks provide financial slack? Journal of Finance, 57(3), 1383-420.

Harris, M., A. Raviv, (1991), “The Theory of Capital Structure”, Journal of Finance 46, 297-355.

Huang, S., Song, F. (2006) The determinants of capital structure: evidence from China, China Economic Review, 17(1), pp.14-36

Krishnan, V. S., and R. C. Moyer, (1997), "Performance, Capital Structure and Home Country: An Analysis of Asian Corporations". Global Finance Journal 8, 129-143.

Margaritis, D., \&Psillaki, M. (2010). Capital structure, equity ownership and firm performance. Journal of Banking \& Finance, 34(3), 621-632.

Modigliani, F., \& Miller, M. H. (1958). The cost of capital, corporation finance, and the theory of investment. American Economic Review, 48(3), 261-297.

Modigliani, F., \& Miller, M. H. (1963). Corporate income taxes and the cost of capital: A correction. American Economic Review, 53(3), 443-453.

Pandey, I. M. (2009), Financial Management: Capital Structure Planning and Policy (pp. 332,333).

Ross, S. A., Westerfield, R., \& Jordan, B. D. (2008). Fundamentals of corporate finance. Tata McGraw-Hill Education.

Saad, N. M. (2010). Corporate Governance Compliance and the Effects to Capital Structure. International Journal of Economics and Financial, 2(1), 105-114.

Serghiescu, L., Vaidean V.L. (2013) Determinant factors of the capital structure of a firm- an empirical analysis, Working paper EMQFB, TgMures 2013

Van Horne, J. C., \&Wachowicz, J. M. (2008). Fundamentals of financial management. Pearson Education.

Velnampy. T. \&NireshAloy J. (2012), The Relationship between Capital Structure \& Profitability. Global Journal of Management and Business Research, Volume 12 Issue 13, 67-74

Weston, J. F., \& Brigham, E. F. (1990). Essentials of managerial finance. Dryden Press.

Zutter, C. J., \&Gitman, L. J. (2011). Principles of Managerial Finance, Brief. Pearson Higher Ed.

\section{Websites}

http://abbl.com

http://blilbd.com/

http://www.bankasia-bd.com

http://www.bracbank.com

http://www.dutchbanglabank.com

http://www.idcol.org/

http://www.ificbank.com.bd

http://www.jamunabankbd.com

http://www.thecitybank.com/

https://www. dhakabank.com

https://www.easternbank.com/

https://www.southeastbank.net/

www.deltabrac.com

www.fasbd.com

www.gspfinance.com

www.kiclbd.com

www.lankabangla.com

www.primefinancebd.com

www.ulc.com.bd

www.uttarafinance.biz. 